\title{
PENGGUNAAN MEDIA KOMIK DAPAT MENINGKATKAN HASIL BELAJAR IPA DI SEKOLAH DASAR
}

\author{
Lutfikah \\ Nurhasanah \\ Sekolah Tinggi Agama Islam (STAI) Bani Saleh \\ JIn. M. Hasibuan No.68 (Lantai 2) Bekasi Timur 17113, Telp/Fax : 021-883 43360 \\ www.staibanisaleh.ac.id e-mail : staibanisaleh@yahoo.co.id \\ lutfikah15@gmail.com.,nurhasanah.juni13@gmail.com
}

Naskah masuk: 16-05-20, direvisi: 21-05-20, diterima: 16-05-20, dipublikasi: 30-04-20

\begin{abstract}
Abstrak: Tujuan penelitian ini adalah untuk meningkatkan hasil belajar IPA melalui media pembelajaran komik pada siswa kelas VA SDN Harja Mekar 04 Cikarang Utara.Subjek penelitian adalah siswa kelas VA yang berjumlah 22 siswa. Metode penelitian yang digunakan dalam penelitian ini adalah Penelitian Tindakan Kelas (PTK). Desain tindakan/ rancangan penelitian menggunakan model Kemmis dan MC Taggart. Hasil yang diperoleh pada setiap siklus adalah siklus I nilai rata-rata hasil beajar IPA melalui media pembelajaran komik adalah $64,04 \%$, siklus II nilai rata-rata hasil belajar IPA meningkat menjadi $86,22 \%$. Hasil dari penelitian ini dapat diketahui bahwa media pembelajaran komik merupakan salah satu media pembelajaran yang baik untuk meningkatkan hasil belajar IPA padasiswa Sekolah Dasar.
\end{abstract}

Kata Kunci: Peningkatan hasil belajar, Media pembelajaran komik, IPA.

\begin{abstract}
The purpose of this study was to improve science learning outcomes through comic learning media for VA class students at SDN Harja Mekar 04 North Cikarang. The research subjects were 22 VA class students. The research method used in this study is Classroom Action Research (CAR). The actiondesign. The results obtained in each cycle is the first cycle the average value of natural science learning outcomes through comic learning media is $64.04 \%$, the second cycle the average value of science learning outcomes increased to $86.22 \%$. The results of this study can be seen that the comic learning media is one of the good learning media for improving science learning outcomes in students Elementary School.
\end{abstract}

Keywords : Improved learning outcomes, Comic learning media, Science.

\section{PENDAHULUAN}

Salah satu mata pelajaran yang diajarkan di Sekolah Dasar adalah IImu Pengetahuan Alam. IImu pengetahuan Alam yang sering disebut dengan istilah sains, disingkat menjadi IPA. IPA merupakan salah satu mata pelajaran pokok dalam kurikulum pendidikan Indonesia, termasuk pada jenjang Sekolah Dasar. IPA adalah usaha manusia dalam memahami alam semesta melalui pengamatan yang tepat pada sasaran, serta menggunakan prosedur, dan dijelaskan dengan penalaran sehingga mendapatkan suatu kesimpulan.

Gagne (2014:44) mengemukakan teori yang disebut The domains of learning, menyimpulkan bahwa segala sesuatu yang dipelajari oleh manusia dapat dibagi menjadi lima kategori, yaitu: (1) keterampilan motoris (motor skill); adalah keterampilan yang diperlihatkan dari 
berbagai gerakan badan, (2) Informasi verbal; informasi ini sangat dipengaruhi oleh kemampuan otak atau intelegensi seseorang, (3) Kemampuan intelektual; selain menggunakan simbol verbal, manusia juga mampumelakukan interaksi dengan dunia luar melalui kemampuan intelektualnya, (4) Strategi kognitif; Gagne menyebutnya sebagai organisasi keterampilan yang internal, (5) Sikap (attitude); sikap merupakan faktor penting dalam belajar karena tanpa kemampuan ini belajar tak akan berhasil dengan baik. Sikap seseorang dalam belajar akan sangat memengaruhi hasil yang diperoleh dari belajar tersebut.

Usman (2016:3) mengemukakan bahwa IPA merupakan IImu yang berhubungan dengan gejala alam dan kebendaan yang sistematis yang tersusun secara teratur, berlaku umum yang berupa kumpulan dari hasil observasi dan eksperimen, sistematis (teratur) artinya pengetahuan itu tersusun dalam sustu sistem, tidak berdiri sendiri, satu dengan lainnya saling berkaitan, saling menjelaskan sehingga seluruhnya merupakan satu kesatuan yang utuh, sedangkan berlaku umum artinya pengetahuan itu tidak hanya berlaku oleh seseorang atau beberapa orang dengan cara eksperimentasi yang sama akan memperoleh hasil yang sama atau konsisten.

Kemampuan hasil belajar IPA siswa kelas VA SDN Harja Mekar 04 Cikarang Utara disesuaikan dengan Kurikulum Sekolah Dasar pada setiap mata pelajaran yang memuat Kompetensi Inti (KI) dan Kompetensi Dasar (KD) pada setiap pembelajarannya.

Berikut ini merupakan $\mathrm{KI}$ KD mata pelajaran IPA pada kelas V Sekolah Dasar yang dibatasi pada materi organ pencernaan manusia dan fungsinya.

\section{Tabel 1. KI - KD Mata Pelajaran IPA Kelas V}

\begin{tabular}{|l|l|}
\hline Kompetensi Inti & \multicolumn{1}{|c|}{$\begin{array}{l}\text { Kompetensi } \\
\text { Dasar }\end{array}$} \\
\hline $\begin{array}{l}\text { 3. Memahami } \\
\text { pengetahuan } \\
\text { faktual } \\
\text { konseptual, dan } \\
\text { procedural }\end{array}$ & $\begin{array}{l}\text { 3.3 Menjelaskan } \\
\text { organpencernaan }\end{array}$ \\
\hline
\end{tabular}

Berdasarkan hasil observasi awal yang telah dilakukan peneliti pada siswa kelas VA SDN Harja Mekar 04 Cikarang Utara, terdapat beberapa masalah yang terjadi khususnya terhadap pembelajaran IPA Sekolah Dasar, diantaranya ialah: (1) siswa merasa jenuh dalam proses pembelajaran IPA, (2) siswa cenderung tidak aktif dalam kegiatan pembelajaran IPA,(3)kurangnya daya tarik siswa terhadap pembelajaran IPA. Selain itu, data tersebut didukung pula berdasarkan hasil wawancara dengan guru kelas VA SDN Harja Mekar 04 Cikarang Utara, adapun masalah-masalahnya: (1) Rendahnya hasil belajar IPA, hal ini terlihat bahwa masih terdapat sekitar $60 \%$ siswa belum memenuhi nilai KKM yang sudah ditentukan oleh sekolah yaitu nilai KKM 70; (2) Minat membaca dan minat belajar siswa terhadap mata pelajaran IPA belum muncul; (3) Kurangnya penerapan media pembelajaran yang bervariasi, hal ini dikarenakan belum tersedianya media atau alat peraga yang digunakan olehguru.

Salah satu upaya untuk mengatasi permasalahan di atas diperlukan media yang tepat untuk digunakan dalam kegiatan belajar mengajar dalam pembelajaran IPA, khususnya pada materi alat pencernaan. Media pembelajaran dapat dijadikan sebagai alat untuk mendorong aktifitas peserta didik dalam pembelajaran, susasana belajar akan lebih hidup dan tidak membosankan.

Media adalah sarana untuk menyampaikan suatu informasi dari suatu 
sumber, dimana sarana disini dapat berupa apa saja yang dapat memberikan atau menjadi sumber informasi. Hal yang senada juga diungkapkan oleh Smaldino, Lowther dan Russel, yang mengungkapkan bahwa media merupakan bentuk jamak dari perantara (medium), yang merupakan sarana komunikasi pada apa saja yang membawa informasi antara sebuah sumber dan sebuah penerima (Smaldino \& Russel 2011: 7). Dari pernyataan tersebut, yang dapat menjadi media atau perantara ialah apa saja yang dapat membantu guru untuk menyampaikan informasi kepada anak, media ini dapat berupa benda, peristiwa maupun manusia. Meningkatkan minat membaca dan minat belajar peserta didik. Salah satu media pembelajaran yang dapat digunakan untuk meningkatkan hasil belajar IPA khususnya materi alat pencernaan pada manusia adalah media pembelajaran komik.

Komik dalam etimologi bahasa Indonesia berasal dari kata "comic" yang kurang lebih secara semantik berarti "lucu", "lelucon" atau kata komikos dari komos 'revel' bahasa Yunani yang muncul sekitar abad ke-16. Menurut M.S Gumelar (2011:2), komik adalah urutan-urutan gambar yang ditata sesuai tujuan \& filosofi pembuatnya hingga pesan cerita tersampaikan. Komik cenderung diberi lattering yang dibutuhkan sesuai kebutuhan. Berdasarkan definisi tersebut dapat diartikan bahwa medium komik tidak harus selalu berupa buku, bisa saja secara tradisional seperti batu, kayu, kanvas dan tidak harus diberi lattering. Oleh karena itu, ada kata "cenderung" yang penulis cetak miring (italic).

Menurut Mohamad Syarif Sumantri (2015:320), Komik merupakan suatu bentuk kartun yang mengungkapkan karakter dan memerankan suatu cerita dalam urutan yang erat dihubungkan dengan gambar dan dirancang untuk memberikan hiburan kepada para pembaca.

Daryanto (2010:28), komik adalah suatu bentuk sajian cerita dengan seri gambar yang lucu. Buku komik menyediakan cerita-cerita yang sederhana, mudah ditangkap dan dipahami isinya sehingga sangat digemari, baik oleh anakanak maupun orang dewasa. Dapat diartikan bahwa komikmerupakan bentuk sajian cerita dengan gambar yang sederhana dan mudah dipahami isinya sehingga banyak disukai oleh kalangan anak-anak maupun dewasa karena penyampaiannya yang menarik dan menyenangkan.

Berdasarkan pendapat para ahli di atas dapat disimpulkan bahwa komik adalah salah satu media pembelajaran yang dapat menarik perhatian siswa dalam mempelajari suatu materi pelajaran karena penyajiannya yang dirancang dalam bentuk kartun yang mengungkapkan karakter dan cerita yang kuat.

\section{METODE}

Metode yang digunakan adalah penelitian tindakan (action research). Penelitian tindakan atau yang lebih dikenal dengan action research, pada prinsipnya dimaksudkan untuk mengembangkan keterampilan atau untuk memecahkan suatu permasalahan di kelas (Handini 2012: 20).

Hal ini ditegaskan oleh McNiff bahwa dasar utama dari metode ini adalah untuk perbaikan dan peningkatan layanan profesional pendidik dalam menangani proses belajar mengajar dengan melakukan berbagai tindakan alternatif dalam memecahkan persoalan pembelajaran. Dalam hal ini peneliti atau guru melakukan sesuatu yang arah dan tujuan penelitiannya sudah jelas, yaitu demi kepentingan peserta didik dalam memperoleh hasil belajar yang memuaskan. Dalam penelitian tindakan terdapat dua aktivitas yang dilakukan secara simultan, yaitu aktivitas tindakan (action) dan aktivitas penelitian (research) (Arikunto 2006: 106). Kedua aktivitas tersebut dapat dilakukan orang yang sama atau orang yang berbeda yang bekerja sama secara kolaboratif. Desain intervensi tindakan/rancangan siklus penelitian ini menggunakan model Kemmis dan Mc. 
Taggart. Prosedur kerja dalam penelitian tindakan menurut Kemmis dan Mc. Taggart dalam Arikunto, meliputi tahap-tahap sebagai berikut : (a) perencanaan (planning), (b) tindakan (acting), (c) observasi (observing), (d) refleksi (reflecting), kemudian dilanjutkan dengan perencanaan ulang (replanning), tindakan, observasi, dan refleksi untuk siklus berikutnya, begitu seterusnya sehingga membentuk suatu spiral.

Penelitian ini menganalisis cara peningkatan hasil belajar IPA Sekolah Dasar melalui penggunaan media komik pada siswa kelas V SDN Harja Mekar 04 Cikarang Utara. Sumber data dalam penelitian ini adalah siswa kelas V SDN Harja Mekar 04 Cikarang Utara yang merupakan sumber data primer yang berjumlah 22 orang dari 34 siswa, Subjek penelitian ini dipilih berdasarkan permasalahan yang terjadi pada siswa kelas VA yaitu rendahnya hasil belajar dalam mata pelajaran IPA. Kemudian kepala sekolah yang dapat memberikan informasi mengenai kegiatan pembelajaran di sekolah, dan kolaborator yang terlibat dalam penelitian yaitu guru kelas.

\section{HASIL DAN PEMBAHASAN}

\section{A. Hasil}

Data penelitian ini dideskripsikan dalam bentuk penyajian data secara kuantitatif dan kualitatif. Data kuantitatif untuk melihat persentase kenaikan pada setiap siklusnya. Sedangkan data kualitatif untuk menganalisis data yang diperoleh melalui catatan lapangan, catatan wawancara, dan catatan dokumentasi di lapangan. Berikut ini merupakan deskripsi data kuantitatif mengenai hasil belajar IPA melalui penggunaan media komik.

Sebelum melakukan program tindakan yang akan dilaksanakan dalam penelitian, peneliti melakukan persiapan prapenelitian, yaitu mencari dan mengumpulkan data-data siswa yang akan diteliti melalui observasi langsung dan melakukan pratest untuk mengetahui sejauh mana kondisi awal hasil belajar IPA. Pada tahap awal siswa diberikan media berupa komik untuk mata pelajaran IPA materi pencernaan pada manusia.

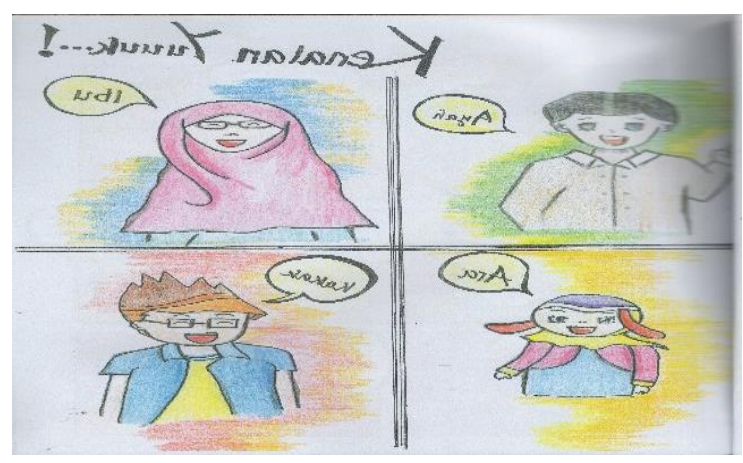

\section{Gambar 1 Perkenalan Tokoh dalam Komik}

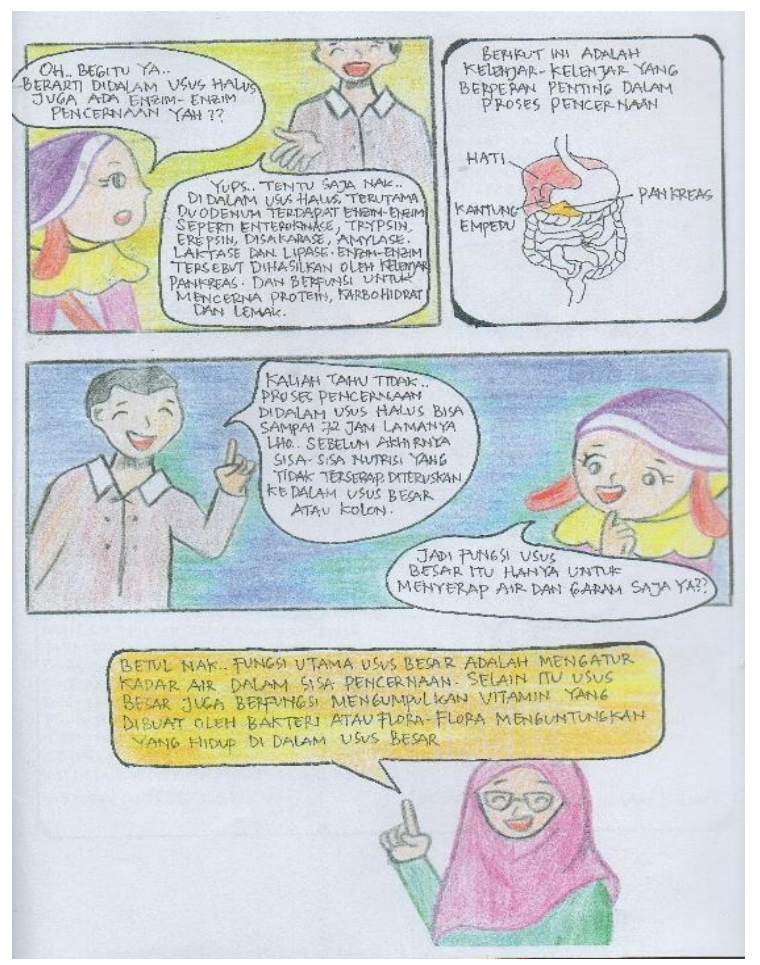

Gambar 2. Isi Komik materi pencernaan pada manusia 
Berdasarkan perolehan data dari hasil tes pra penelitian, maka dapat dilakukan tindakan proses pembelajaran pada tahap siklus. Deskripsi data pada siklus I dan siklus II terdiri dari data kualitatif dan data kuantitatif. Data kualitatif terkait dengan perencanaan tindakan, pelaksanaan tindakan, catatan observasi, dokumentasi dan refleksi dari implementasi tindakan yang telah dilaksanakan. Adapun data kuantitatif pada siklus I dan II dilakukan secara bertahap selama 4 kali pertemuan dalam masing- masing siklus.

Tabel 2 Perbandingan Data Pra Penelitian, Siklus I dan Siklus II

\begin{tabular}{|c|c|c|c|c|c|c|c|c|}
\hline \multirow{2}{*}{ No } & \multirow{2}{*}{ Nama } & Pra Penelitian & \multicolumn{2}{c|}{ Siklus I } & \multicolumn{2}{c|}{ Siklus II } & \\
\cline { 3 - 8 } & Skor & $\begin{array}{c}\text { Prosentase } \\
(\%)\end{array}$ & Skor & $\begin{array}{c}\text { Prosentase } \\
(\%)\end{array}$ & Skor & $\begin{array}{c}\text { Prosentase } \\
(\%)\end{array}$ & Keterangan \\
\hline 1 & ANI & 12 & 34 & 18 & 51 & 27 & 77 & Meningkat, Tercapai \\
\hline 2 & AS & 19 & 54 & 23 & 66 & 28 & 80 & Meningkat, Tercapai \\
\hline 3 & DMM & 15 & 43 & 21 & 60 & 29 & 83 & Meningkat, Tercapai \\
\hline 4 & DAW & 16 & 46 & 25 & 71 & 29 & 83 & Meningkat, Tercapai \\
\hline 5 & JIA & 12 & 34 & 19 & 54 & 27 & 77 & Meningkat, Tercapai \\
\hline 6 & KA & 16 & 46 & 23 & 66 & 28 & 80 & Meningkat, Tercapai \\
\hline 7 & KM & 20 & 57 & 27 & 77 & 33 & 94 & Meningkat, Tercapai \\
\hline 8 & KAB & 16 & 46 & 21 & 60 & 31 & 88 & Meningkat, Tercapai \\
\hline 9 & LP & 17 & 48 & 21 & 60 & 31 & 88 & Meningkat, Tercapai \\
\hline 10 & LG & 13 & 37 & 18 & 51 & 29 & 83 & Meningkat, Tercapai \\
\hline 11 & MAL & 17 & 48 & 25 & 71 & 30 & 86 & Meningkat, Tercapai \\
\hline 12 & MFM & 16 & 46 & 23 & 66 & 31 & 88 & Meningkat, Tercapai \\
\hline 13 & MH & 13 & 37 & 20 & 57 & 29 & 83 & Meningkat, Tercapai \\
\hline 14 & MS & 11 & 31 & 19 & 54 & 29 & 83 & Meningkat, Tercapai \\
\hline 15 & NS & 17 & 48 & 21 & 60 & 28 & 80 & Meningkat, Tercapai \\
\hline 16 & RNR & 18 & 51 & 28 & 80 & 35 & 100 & Meningkat, Tercapai \\
\hline 17 & SA & 18 & 51 & 29 & 83 & 35 & 100 & Meningkat, Tercapai \\
\hline 18 & SAG & 15 & 43 & 23 & 66 & 31 & 88 & Meningkat, Tercapai \\
\hline 19 & SAF & 14 & 40 & 25 & 71 & 33 & 94 & Meningkat, Tercapai \\
\hline 20 & VRP & 15 & 43 & 25 & 71 & 32 & 91 & Meningkat, Tercapai \\
\hline 21 & YH & 16 & 46 & 21 & 60 & 31 & 88 & Meningkat, Tercapai \\
\hline 22 & ZNH & 12 & 34 & 19 & 54 & 29 & 83 & Meningkat, Tercapai \\
\hline Jumlah Skor & 338 & 963 & 494 & 1409 & 665 & 1897 & \\
\hline Nilai rata- & 14,36 & 43,77 & 22,45 & 64,04 & 30,22 & 86,22 & Meningkat, Tercapai \\
& rata & & & & & & & Meningkat, Tercapai \\
\hline $\begin{array}{r}\text { Keterca- } \\
\text { paian }\end{array}$ & 0 & 0 & 7 & 31,81 & 22 & 100 & \\
\hline Siswa & & & & & & & \\
\hline
\end{tabular}


Berdasarkan tabel perbandingan di atas, dapat dilihat bahwa hasil belajar IPA siswa kelas VA mengalami peningkatan, terlihat dari jumlah siswa yang mencapai KKM bertambah setiap siklusnya dari mulai tes pra penelitian, siklus I, dan siklusll,dengan nilai rata-rata akhir yang diperoleh yaitu 70. Berikut perbandingan data pra penelitian, siklus I dan siklus II pada masing-masing siswa dalam bentuk grafik.

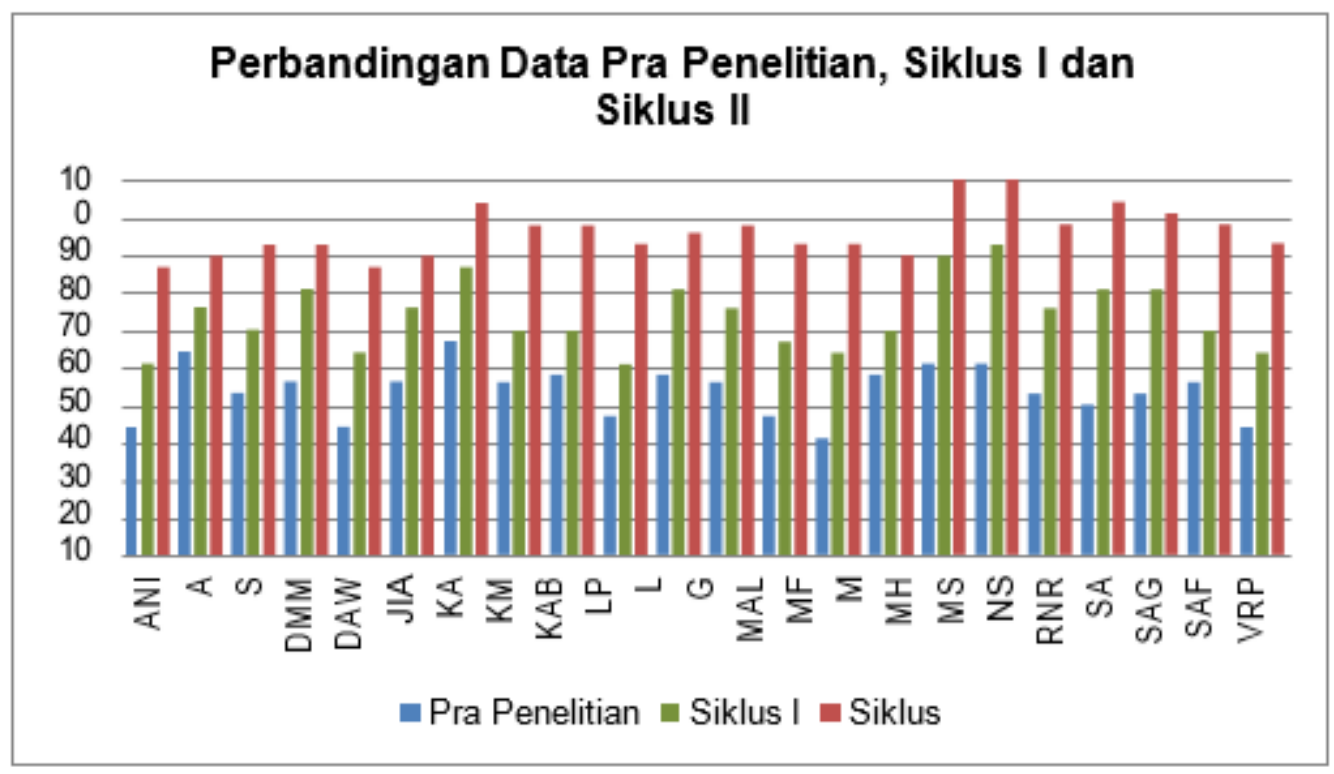

\section{Gambar 3 Grafik data perbandingan pra penelitian, siklus I dan Siklus II}

\section{B. Pembahasan}

Serangkaian pelaksanaan tindakan penelitian yang dilakukan pada tes pra penelitian, siklus I, dan siklus II memperlihatkan ketercapaian hasil penelitian tindakan yang diharapkan, yaitu meningkatkan hasil belajar IPA siswa kelas VA SDN Harja Mekar 04 Cikarang Utara.

Peneliti melakukan perbandingan data analisis dari data pra penelitian, tindakan siklus I, sampai pada tindakan siklus akhir yaitu siklus II. Hasil belajar IPA pada pra penelitian yaitu memperoleh rata-rata $43,77 \%$ kemudian mengalami peningkatan setelah diberi tindakan pada siklus I yaitu dengan rata-rata $64,04 \%$, dan kemudian mengalami peningkatan kembali setelah diberikan tindakan pada siklus II yaitu dengan memperoleh rata- rata sebesar $86,22 \%$. Dengan perolehan nilai diatas KKM yaitu 70 maka penelitian ini dianggap sudah mencapai target yang telah ditentukan. Tindakan ini berakhir pada siklus II.

Adapun data prosentase dari pra penelitian sampai pada tindakan siklus I kemudian pada akhir siklus II hasil belajar IPA mengalami peningkatan. Hal ini terlihat dari perkembangan interaksi siswa ketika kegiatan pembelajaran. Berikut peneliti sajikan tabel perbandingan kenaikan prosentase dari data awal pra penelitian, siklus I dan siklus II.

Tabel 3 Peningkatan Hasil Prosentase

Pra Penelitian, Siklus I, dan Siklus II 
Berdasarkan tabel di atas, terbukti bahwa penggunaan media pembelajaran komik dapat meningkatkan hasil belajar IPA pada siswa kelas VA SDN Harja Mekar 04 Cikarang Utara. Penggunaan media pembelajaran komik yang relatif dan tidak membuat siswa merasa jenuh serta dapat dikaitkan dengan kehidupan sehari-hari, memberikan kesan pembelajaran yang baik dan menyenangkan bagi siswa.

\section{PENUTUP}

Kegiatan pembelajaran dengan media pembelajaran komik cukup efektif untuk meningkatkan hasil belajar IPA siswa, hal ini terlihat dari nilai-nilai siswa sebelum diberikan tindakan sampai pada tahap diberikan tindakan. Pada tahap pra penelitian, belum terlihat indikator hasil belajar IPA yang tercapai. Pada siklus I sudah mulai terlihat peningkatan yang cukup baik, terdapat 7 siswa yang

\begin{tabular}{|c|c|c|c|c|}
\hline Pra Pen. & $\begin{array}{c}\text { Pening- } \\
\text { katan }\end{array}$ & Siklus I & $\begin{array}{c}\text { Pening- } \\
\text { katan }\end{array}$ & $\begin{array}{c}\text { Siklus } \\
\text { II }\end{array}$ \\
\hline $43,77 \%$ & $20,27 \%$ & $64,04 \%$ & $22,18 \%$ & $86,22 \%$ \\
\hline
\end{tabular}

mengalami peningkatan sesuai standar KKM yang ditentukan dan 15 orang siswa belum mencapai KKM, meskipun sudah mengalami peningkatan jika dibandingkan dengan pra penelitian. Pada siklus II semua siswa mengalami peningkatan dan mencapai target KKM yang ditentukan serta memperoleh skor ketercapaian 100\%.

\section{UCAPAN TERIMA KASIH}

Puji syukur peneliti persembahkan kepada Allah SWT. karena berkat rahmat dan hidayah-Nya peneliti dapat menyelesaian penelitian ini. Tak lupa juga peneliti ucapkan terimakasih yang sebesarbesarnya kepada dosen pembimbing yang selalu memberikan arahan dan motivasi. Begitu juga kepada seluruh pihak yang telah memberikan bantuan dan dukungan untuk menyelesaikan penelitian ini.

\section{REFERENSI}

Arikunto, S. (2006). Penelitian Tindakan Kelas. Jakarta: Bumi Aksara.

Daryanto (2010). Media Pembelajaran. Bandung: Satu Nusa.

Handini, M. C. (2012). Metodologi Penelitian untuk Pemula. Jakarta: FIP Press.

Gumelar, M.S. (2011). Cara Membuat Komik. Jakarta: Indeks.

Samatowo, U. (2016). Pembelajaran IPA Sekolah Dasar. Jakarta: PT. Indeks.

Smaldino, S. E., Deborah L. Lowther, James D. Russel (2011). Instructional Technology \& Media For Learning. Edisi Kesembilan. Jakarta: Kencana.

Sumantri, M. S. (2015) Strategi Pembelajaran (Teori dan Praktik di Tingkat Sekolah Dasar). Jakarta: Rajawali Press. 